\title{
An Assessment of the Takamanda-Mone Landscape as a Potential Forest Habitat for the African Forest Elephant (Loxodonta africana cyclotis) in the South West Region of Cameroon
}

\author{
Nkwatoh Athanasius Fuashi ${ }^{1}$, Victor Chik Fosah ${ }^{2} \&$ Melle Maurice Ekane ${ }^{1}$ \\ ${ }^{1}$ Department of Environmental Science, University of Buea, Cameroon \\ ${ }^{2}$ Environmental Education, Conservation and Research (EECORE), Cameroon \\ Correspondence: Nkwatoh Athanasius Fuashi, Department of Environmental Science, P. O. Box 63, University \\ of Buea, South West Region of Cameroon. E-mail: nkwatohaf@gmail.com
}

Received: September 3, 2012 Accepted: November 20, 2012 Online Published: February 7, 2014

doi:10.5539/enrr.v4n1p64 URL: http://dx.doi.org/10.5539/enrr.v4n1p64

\begin{abstract}
The Humid Forest Zones (HFZ) of Central Africa, have relatively been understudied in the area of their potentials as large mammals habitats. This is particularly true for forest elephants which are predominantly migratory across large ecological landscapes. This migratory phenomenon makes it difficult to state with certainty their status and habitat need in time and space that can help conservationist and policy makers to designate /classify a landscape as a large mammal (elephant) habitat. It was from this backdrop of uncertainty that this study on the Assessment of the Takamanda-Mone landscape as a potential forest habitat for the African forest elephant (Loxodonta africana cyclotis) in the South West Region of Cameroon was consecrated. The study in order to achieve set objectives, made use of Socio-economic surveys that involved the use of questionnaire, some selected Participatory Rural Appraisal (PRA) tools. Biological assessment techniques such as transects, poacher guided survey as well as the use of the Geographic Information System (GIS), techniques were employed for data collection and analysis. Results revealed that the Takamanda-Mone landscape is a potential forest habitat for the African forest elephant (Loxodonta africana cyclotis). Their presence and migration in and out of the study area is known to be affected by the two seasons (dry and wet) that prevail in the areas. Their presence was found to be more marked in the wet and low in the dry season. Results further revealed that evidences of the African forest elephants (Loxodonta africana cyclotis) presence in the study area ranged from physical encounters and observation of the animals, left over of crops destroyed, recorded vocalisations of the animals far-off villages, forest fruits devastation, fresh and old forest tracks, footprints, feeding signs, debarking and felling of trees to dung droppings. The evidence of direct encounter and observing the animals was strongly associated with the older population (40 years and above). Result also showed that during some of the direct encounters with the population, the African forest elephants were known to have killed about 10 persons and injured about 17 persons over the past 25 years in the study area. Conclusively, the study area is a habitat for the African Forest elephant (Loxodonta africana cyclotis) and is being recommended to be designated as a habitat for the protection of species and other wildlife species.
\end{abstract}

Keywords: African forest elephant, presence, habitat, Takamanda-Mone landscape

\section{Introduction}

Some protected areas within the Humid Forest Zones (HFZ) of Central and West Africa are known in the light of their large mammal's potentials and the uniqueness of the area's ecology and ecosystems dynamics (Mboh \& Warren, 2007; Sebogo, 2006; Whitehouse, 2002). This is particularly true for habitats such as the Zanga Zanga National Park in the Central African Republic, the Dja National Park in Cameroon and the Cross River National park in Nigeria for their large populations of the African forest elephant. Though these large animal populations are attributed to these habitats, they are predominantly migratory across large ecological landscapes that spans across regional and international frontier zones (Tchamba \& Seme, 1993; WWF Cameroon, 2003; SunderlandGroves et al., 2003; Blom, 2001). This phenomenon of constant movement makes it difficult to state with certainty the exact population of these animals within a given habitat in time and space that can help Researchers , Conservationist and policy makers to designate or classify a particular landscape as an actual forest elephant 
habitat (Epiemelle \& Ekobo, 2003; Tchamba \& Seme, 1993; O'kah, 2003). This limitation is not unconnected to the difficulty that underpins various methodologies used in the estimation of wildlife populations. This is particularly common with forest elephants as they are not easily seen like those in the grassland areas (IUCN, 2009; Blake, 2005; Blanc et al., 2007; Blanc, 2008). As a result of these difficulties in wildlife population estimates, forest elephants have been studied using indirect methods that take on board the use of specific signs such as dung, footprints, feeding signs, tree debarking and many others (White, 1993; Nchanji \& Plumetre, 2003; Vick, 2003; Le Breton et al., 2003). Though forest habitat and its wildlife resources seem to have a lot of gaps that need to be closed in the HFZ of Central and West Africa, the African forest Elephants (Loxodonta africana cyclotis) and its habitats however, have been extensively studied in some protected and unprotected areas in the sub region. Prominent scientists, research organisations, NGOs and many other interested constituted cores have carried out research on the ecology, migratory patterns, human-elephant conflicts, genetics as well as the species conservation and management. Among these are studies of Mboh and Warren (2007), Sunderland-Groves et al. (2003) who studied the Large Mammals and specifically the Biodiversity of the Takamanda-Mone Landscape of the South West Region of Cameroon. In the same vein, Tchamba and Seme (1993), WWF Cameroon (2003), Blake (2005), Blanc et al. (2007) assessed the population distribution of the African forest elephants (Loxodonta africana cyclotis) in the Central African Forests zones. Sebogo (2006) is known to have developed an action Plan for the management of the African forest elephants in the Ziama-Wenegesi Transfrontier corridor of Guinea. Ekobo $(1994,2003)$ in addition to the works of WWF Cameroon, established the presence of the African forest elephants (Loxodonta africana cyclotis) in the Mount Cameroon forest area of the South West Region and the Dja National Park in the Eastern Region of Cameroon. On the bench of human elephant conflicts, Epiemelle and Ekobo (2003), Nkwatoh and Fosah (2012) assessed the level of human-elephant conflict in the mountain forest area of South West Cameroon. On the other hand, Nchanji and Plumetre (2003) evaluated the seed dispersal phenomenon and germination by the African forest elephant in the Bayang-Mbo Sanctuary of the South West Cameroon.

Despite all these research efforts, wildlife habitat (large mammals) sector in general and the African forest Elephants (Loxodonta africana cyclotis) in particular in Cameroon, Central and West Africa at large, is still challenged by a series of problems. One of these problems is the low level of correlated research efforts that clearly demonstrates the presence of these species in key habitats that can act as a driving force for the elaboration of policies for the protection and preservation of these habitats and corridors (IUCN, 2009).

As part of the national and international strive to source adequate information, on what constitutes the national potentials of wildlife (large mammals) habitats in general and specifically the African forest Elephants (Loxodonta africana cyclotis) forest habitat in particular, this study on the Assessment of the Takamanda-Mone landscape as a potential forest habitat for the African forest elephant (Loxodonta africana cyclotis) in the South West Region of Cameroon was initiated. To achieve study target, the study had as objectives:

1) To assess the bench marks (signs/evidence) for elephant presence in the study area.

2) To assess the impact of season on elephant presence in the study area.

3) To evaluate the study area as a potential habitat for African forest elephants Conservation

\section{Materials and Method}

\subsection{Location of Study Area}

The Takamanda-Mone Landscape is located between latitude $5^{\circ} 55^{\prime}-6^{\circ} 21^{\prime} \mathrm{N}$ and longitude $9^{\circ} 11^{\prime}-9^{\circ} 33^{\prime} \mathrm{E}$ covering a surface area of about $676 \mathrm{~km}^{2}$. It shares its western border with the Okwango Division of the Cross River National Park in Cross River State of Nigeria. It is bounded to the South by River Manyu (Cross River) in the East by the Mamfe-Widikum road and in the North by the Kweguini highlands in the Njinkwa Sub Division of North West Region of Cameroon (MINIPAT, 1987). The vegetation of the study area is of the GuineaCongolian type (White, 1993). It is dominated by a humid tropical climate, characterized by a single short dry season (November- March) and a corresponding long wet season (April-October), (Mboh \& Warren, 2007). The mean annual rainfall for the period of the study (2008-2011) was about $2400 \mathrm{~mm}$ with monthly peaks in July and August of every year (Bisongabang Weather Station, 2011). The mean monthly temperature ranged between $24{ }^{\circ} \mathrm{C}$ and $27{ }^{\circ} \mathrm{C}$ in February and January respectively and a maximum of $28.2{ }^{\circ} \mathrm{C}$ in March of every year, (Bisongabang Weather Station, 2011). It is drained principally by River Manyu (Cross River) and its multiple tributaries (Sunderland-Groves et al., 2003). 


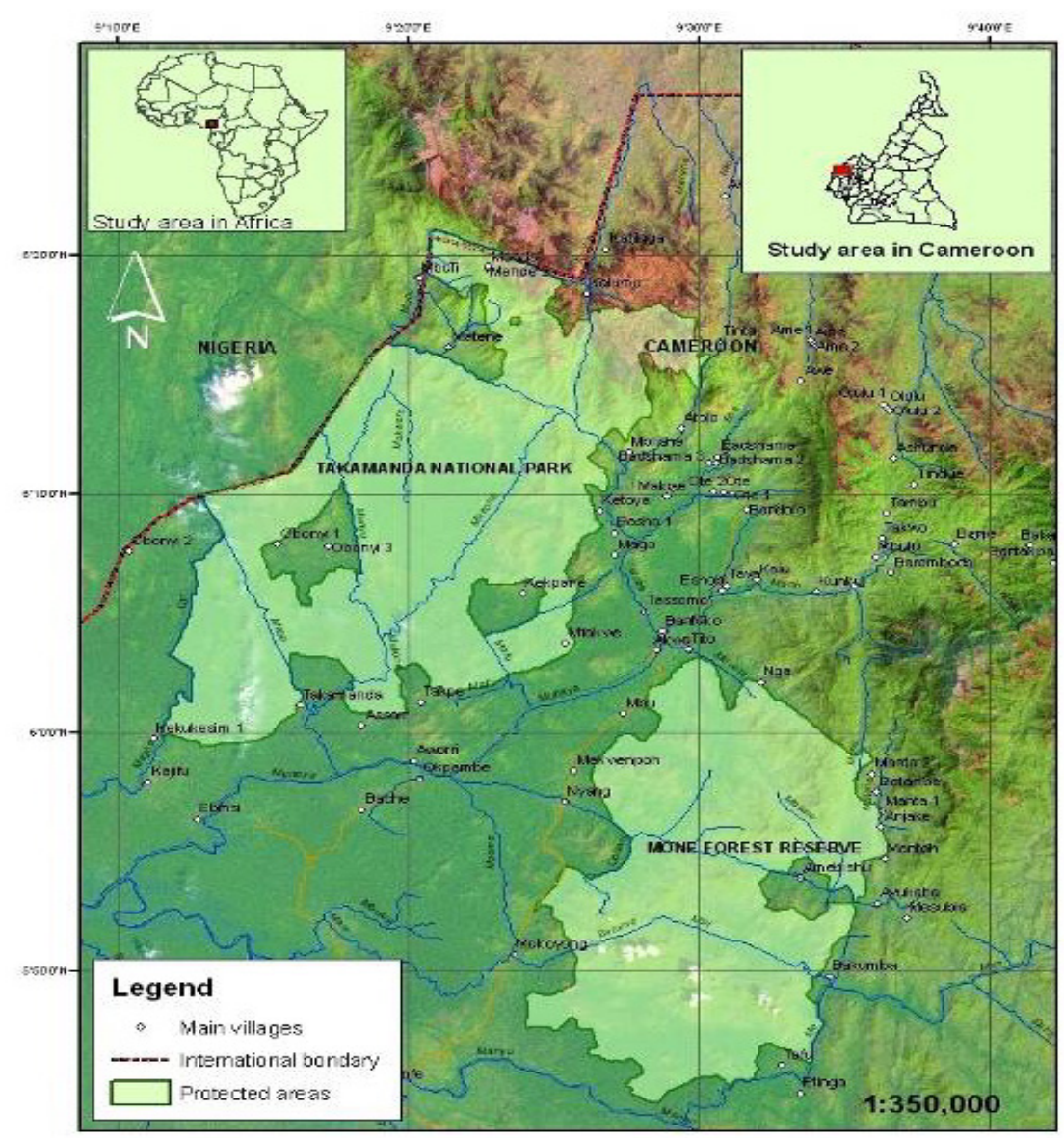

Figure 1. Map of study area: Takamanda-Mone Landscape

\subsection{Methodology}

The study employed Biological and socio-economic assessment techniques. Biological assessment took the form of line transect establishment and a hunter guided survey. The socio-economic technique made use of the random and purposive sampling methodology for the selection of villages and the respondents for questionnaire administration. Alongside these sampling techniques, some selected Participatory Rural Appraisal (PRA) tools, such as focused group discussions, transect walk, seasonal calendar, historical time line, triangulation, visual assessments, and key informants, were employed for the collection of data on the bench marks (signs/evidence) for elephant presence, impact of season on elephant presence, and elephant habitat use. The methodologies further evaluated the study area's potential as a habitat for the Conservation of the African forest elephant (Loxodonta africana cyclotis).

A total of 18 out of 27 villages (Nyang, Mbu, Akwa, Tassomo, Basho 1, Basho 2 (Ketoya), Mbelishe, Matene, Kekpane, Obonyi 3, Obonyi 1, Takpe, Mfakwe, Takamanda, Kajifu. Tito, Asam, Ketoya,) were selected for the study. The 18 villages were purposefully selected on the bases of their location in the Takamanda National Park and its adjoining forest and the Mone forest reserve and its adjoining forest that forms the Takamanda-Mone landscape (T-ML). In each of the 18 villages, 50 questionnaires were administered per village, giving a total of about 900 questionnaires in all with a sampling intensity of about $33 \%$ for the study.

\subsection{Selection of Respondents}

Respondents to the questionnaire were Staff of the Ministry of Forestry and Wildlife, Village Chiefs, Village Traditional Council members, College of elders, hunters, elephant hunters, None-Timber Forest Products (NTFPs) species harvesters/collectors, trappers, farmers, women, youths and other forest users.

These groups of respondents were targeted because they were deemed to treasure a wealth of knowledge about the presence of the African forest elephant in the study area. 


\subsection{Questionnaire Design}

One set of questionnaire divided into three sections A, B, and C was used for the conduct of the study. Sections A and $\mathrm{B}$ of the questionnaire which was made up of open ended questions in conjunction with appropriate PRA tools, gathered information on the background of the respondents and their general awareness of the African forest elephant presence in the study area. On the other hand, section $C$ which was made up of a mixture of open ended and close questions in conjunction with appropriate PRA tools, collected information on respondents personal encounter with elephants. These personal encounters included; seeing the animals from a distance, heard sounds, seen signs of elephants, as well as news of elephant's presence in the study area. In view of the fact that about $90 \%$ of the respondents could not read and write, focused group discussions and semi structured interviews were held with respondents using the questionnaire as a check list (guide) while the note taker completed the questionnaire as the interview session progressed to the end.

\subsection{Biological Assessment Technique}

In order to complement the socio-economic data collection on the assessment of the Takamanda-Mone landscape as a potential forest habitat for the African forest elephant (Loxodonta africana cyclotis) in the study area, the line transect technique as described by Sunderland and Tchouto (1999), Burnham et al. (1980) and Buckland et al. (1993) was employed. In each of the selected villages in the study area, three $5 \mathrm{~km}$ long line transects were established at a distant of $2 \mathrm{~km}$ apart in each habitat type (primary forest, secondary forest, farmlands). These transects were established at a predetermined compass bearing, perpendicular to the main access path from the village into these habitat types and parallel to each other. Along each transect, within the range of $20 \mathrm{~m}$ on both sides of the central line, a 100\% search and recording of all African forest Elephants (Loxodonta africana cyclotis) signs/evidence such as seeing of the animal, left over of crops destroyed, sounds of the animals, forest fruits devastation, fresh and old forest tracks, footprints, feeding signs, debarking, felling of trees and dung droppings were carried out. Beside the transect technique a poacher-guided survey technique was carried out. This exercise took the form of a team of six knowledgeable elephant poachers and four researchers. The constituted team under the guidiance of the poachers moved through each of the habitat types in search of indicators (signs/evidences) for the presence of the African forest Elephants (Loxodonta africana cyclotis). The first two poachers guided the team along the Kekpane, Matene and Mbilishe area. The second batch of two poachers guided the team along the Obonyi 1, Obonyi 3 and Takamanda sections of the forest while the third batch of poachers guided the team along the Mone Forest Reserve area. The poachers guided survey exercise which lasted for 54 days, started at 9:00 am and ended at 4:00 pm of each day. This was carried out in the two seasons (27 days in the dry and 27 days in the wet). The choice of this daily time span was because at this time of the day, light intensity on the forest floor was bright enough to permit visibility of these signs being searched for. During the survey, as soon as a sign was found, the GPS position was taken.

\section{Data Analysis}

Data from the questionnaire were analyzed using Microsoft Excel version 2010 and the Statistical Package for the Social Sciences (SPSS) Version 17. Data from the poacher -guided survey were analysed using ARCGIS version 8.4. Scanned maps were registered using Universal Transverse Mercator (UTM), Zone 32N, with WGS 84 as datum. The maps were then digitised as shaped files in ArcMap. The ground position of the identified points were recorded with the aid of a GPS, Garmin 60CSx, input into Excel 2010, saved as database files (DBF4) and added into ArcMap.

\section{Results}

As shown in Table 1, the study area (T-ML) is a potential habitat for the African forest Elephants (Loxodonta africana cyclotis). 
Table 1. Categories of signs/evidence for African forest elephant presence recorded between 2008-2011

\begin{tabular}{lcc}
\hline No. & Categories of Signs/evidence for elephant presence & $\begin{array}{c}\text { Average No. of signs/evidence for } \\
\text { elephant presence recorded per year }\end{array}$ \\
\hline 1 & physical encounters and seeing of elephants & 11 \\
2 & tree debarking & 33 \\
3 & Farms (crops destroyed) & 3 \\
4 & footprints & Count less \\
5 & dung droppings & 57 \\
6 & fresh and old forest tracks & 17 \\
7 & tree felling/forest fruits devastation & 73 \\
8 & sounds of the animals & 133 \\
9 & Elephant meat on market & 2 \\
\hline
\end{tabular}

In accordance with Table 1, the nine categories of Signs/evidence used for the assessment of the presence of the African forest Elephant (Loxodonta africana cyclotis).in the study area recorded a $100 \%$ acceptance by respondents of the presence of these animals in the study area.

Investigation of the level of association between the respondents' age groups and their physical encounter with the African forest elephants using the Chi square $\left(\chi^{2}\right)$ test, revealed a significant relationship between the age group of 40 years and above at $p<0.05$ level of significance and no significant relationship between the age group of the respondents lower than 40 years.

As shown in Figure 3, Analysis from the Biological and hunter guided survey concluded that the nine categories of Signs/evidence used for the assessment of the presence of the African forest Elephant (Loxodonta africana cyclotis) were recorded on the ground as a complement of the socio-economic survey. The biological investigation as mapped out in Figure 3, further revealed that the ground location of these animals is concentrated along the central stretch of the Takamanda National Park (TNP) and its adjoining forest, with a few movements to the northwestern part of the National Park. In the Mone Forest Reserve (MFR) and its adjoining forest area, these animals are found in the northwestern part of the reserve. 


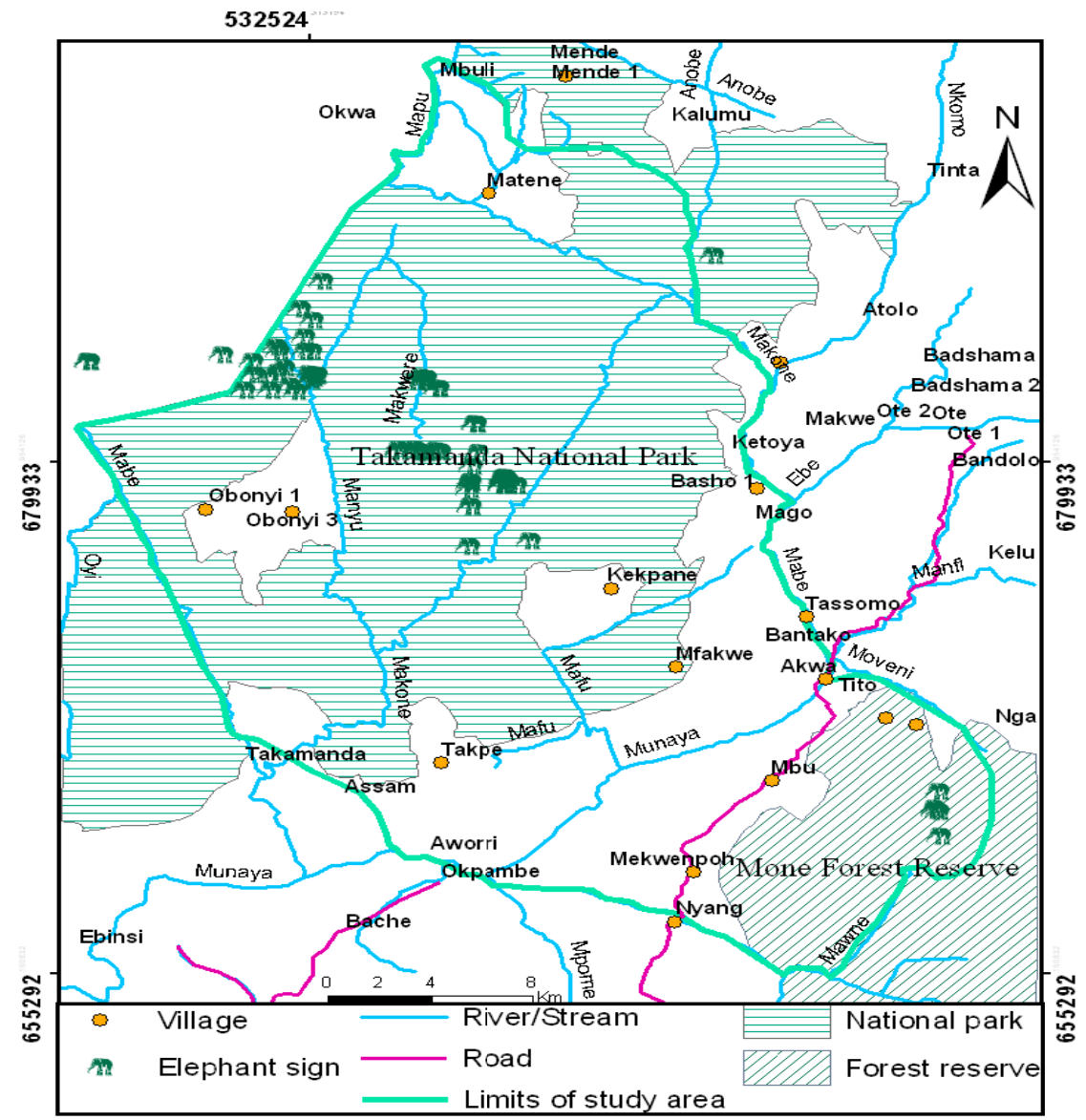

Figure 3. Map showing the African forest elephant signs and habitats in Takamanda-Mone Landscape

The African forest elephant (Loxodonta africana cyclotis) habitat analysis with respect to altitude as shown in figure 4, revealed that the animals are generally located between 122 and $302 \mathrm{~m}$ above sea level with permanent habitat concentrations between 120-200 m altitudes. There was a weak positive correlation between the African forest Elephants (Loxodonta africana cyclotis) location and the altitude as demonstrated by the regression coefficient of 0.2832 as shown in Figure 4. In responses to the two seasons that prevails in the study area, the animals were found to be more present in the wet season (March-October) while the dry season (NovemberFebruary) was characterized by a high level of migration out of the study area to the Cross River National Park in Nigeria and sometimes to the Bayang-Mbo Sanctuary in Cameroon in search of food and tranquility.

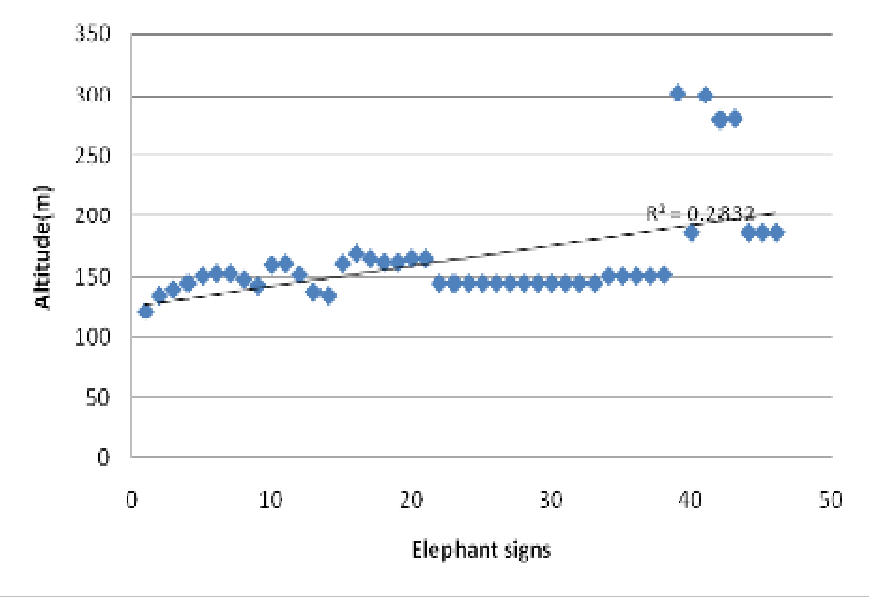

Figure 4. Altitudinal variation of the African forest Elephants (Loxodonta africana cyclotis) habitat location 


\section{Discussion}

African forests elephants (Loxodonta africana cyclotis) are present in the Takamanda-Mone Landscape as 100\% of the respondents confirmed that the eight benchmarks (evidence/signs) used in the assessment of their presence were all positive. This is in conformity with the work of Mboh and Warren (2007), Sunderland-Groves et al. (2003) who studied the Biodiversity of the Takamanda-Mone Landscape of the South West Region of Cameroon and found out that the African forest elephant is part of the area's biodiversity. However, the leading perception was that $100 \%$ of the respondents had heard about the presence of the African forest elephant in the study area. This is in line with the findings of White (1993), Nchanji and Plumetre (2003) who in their separate studies affirmed that hearing about large mammals' presence in a habitat as emerged in recent years as the most commonly treasured evidence to mark the presence of large mammals in key areas amongst forest people. This is probably accounted for by the fact that this benchmark (evidence/signs) type can be possessed without close proximity to the elephant habitat (Vick, 2003; Le Breton et al., 2003). On the other hand, the strength of benchmarks (evidence/signs) enumerated by the respondents, was strongly related to their age groups and sex. This analogy stems from the fact that the registration of the three strongest benchmarks (evidence/signs) categories of elephant presence (seeing elephants, hearing elephant sounds and seeing elephant signs) in the study area was highly registered within the older population (40 years and above) than amongst the younger population $(<40$ years) at $\mathrm{P}<0.05$. This could possibly be due to the fact that the old were present when elephant populations in the recent past in the study area were still very high and as a result, physical encounters with these animals were common. On the other hand, this could be due to the fact that the old visited the forest more than the young as they were more dependent on the forest for their survival (poachers, trappers, NonTimber Forest products (NTFPs) collectors) than the young people of today who on the contrary are more into Agriculture, Education, travelling and trading with a resultant effect of less forest visits comparatively (Epiemelle \& Ekobo, 2003; Tchamba \& Seme, 1993).

The African forest Elephant population and range were confirmed to have increased in the study area from the evidence provided by the Biological Assessments. The 2008-2009 periods showed a relatively high trend with respect to the highest number of elephants observed. Troops of about 41-60 elephants were seen in the 20082009 periods. This increase in the elephant population and range in the T-ML might have been encouraged by the creation of the Takamanda National Park (TNP) in 2008, which might have encouraged the trans-frontier movement of the animals from the Cross River National Park in Nigeria into the study area (Bekhuis \& Prins, 2003). This agrees with Whitehouse (2002), Blanc (2008) who found that the populations of African forest elephants are experiencing a great increase throughout their range state because of the legal protection the elephants now enjoy frorm conservation activities in the study area. This is also in line with Whitehouse (2002) and Sebogo (2006) whose work in the Addo elephant National Park (South Africa) and Cabinda (Angola) respectively realized that a decrease in human activities resulted into a potential increase in elephant presence in these locations.

African forest elephant presence in the Takamanda National Park is predominantly in the wet season around the central part of the Takamanda National Park with an extension towards the northwestern edge of the park. The concentration of these animals along the above described axis is not unconnected to the suitable topography and the flora constitution therein. This is in conformity with White (1994), Tchamba and Seme (1993), Mboh and Warren (2007) who in their separate studies, demonstrated that flora species such as Irvingia gabonensis, a major food source of the animals influences the movement of the African forest elephant in the humid forest zones of Central Africa.

\section{Conclusion}

Conclusively, African forest elephants had been and are still present in the Takamanda-Mone Landscape with the wet season recording higher numbers. The older people have more concrete evidences concerning elephant presence in this area than the younger population.

The animals are concentrated along the central stretch of the TNP with movements from the central stretch to the northwestern part of the park. The population and the range of these animals are on the increase.

\section{Recommendations}

1) More Eco-guards should be recruited to safeguard the integrity of the T-ML.

2) Elephant population inventory studies should be carried out.

3) Migratory patterns of these animals in and around the study area could be monitored for and effective planning and use of the area as a tourist destination. 


\section{Acknowledgements}

We wish to thank profoundly the staff of the German International Cooperation (GIZ) and the Wildlife Conservation Society (WCS), especially the late Dr. Ymke Warren, for their support.

\section{References}

Bekhuis, P., \& Prins, H. H. T. (2003). Forest elephant density and distribution of the Southeastern part of the Campo-Ma'an National Park, Cameroon. Pachyderm, 35, 47-52.

Besongabang Weather Station. (2011). Monthly weather report: for the Provincial Delegation of Weather Observation and Monitoring, South West Province Cameroon (pp. 11-17).

Blake, S. (2005). Central African Forests: Final Report on Population Surveys (2003-2004). March 2005. Nairobi CITES $\quad$ MIKE. $\quad$ Retrieved form http://wwwicites.org?common/program/mike/surveys/central_africa_survey 03-04.pdf

Blanc, J. (2008). 2008 IUCN Red List of Threatened Species. Loxodonta africana. Retrieved form http://www.iucnredlist.org

Blanc, J. J., Barnes, R. F. W., Craig, G. C., Dublin, H. T. C. R., Douglas-Hamilton, I., \& Hart, J. A. (2007). African elephant status report 2007: An update of the African Elephant Database. Occasional Paper Series of the IUCN Species Survival Commission (p. 276). IUCN/SSC African Elephant Specialist Group. IUCN, Gland, Switzerland.

Blom, A. (2001). Ecological and economic impacts of gorilla-based tourism in Dzanga Sangha, Central African Republic. PhD dissertation, University of Wageningen, Wagningen, the Netherlands (Unpublished).

Buckland, S. T., Anderson, D. R., Burnham, K. P., \& Laake, J. L. (1993). Distance Sampling: Estimating abundance of Biological populations (Vol. 53 No. 14, pp. 7-243). London: Chapman and Hall. http://dx.doi.org/10.1007/978-94-011-1572-8

Burnham, K. D., Anderson, D. R., \& Laake, J. L. (1993). Estimation of density from line transects sampling of Biological populations. Wildlife Monographs (Vol. 72 No. 72, pp. 7-202).

Ekobo, A. (1994). Personal Communication: Tables of Estimates Provided at the African Elephant Specialist Group, Mombassa, Kenya, 1994. Document given to African Elephant Specialist Group.

Ekobo, A. (2003). Preliminary forest elephants (Loxodonta africana cyclotic) Survey in mount Cameroon Forest, January- March, 2003.

Epiemelle, W., \& Ekobo, A. (2003). Preliminary Assessment of Human-Elephant conflict in the mount Cameroon region (p. 22). Commissioned by the GTZ- Mount Cameroon Project. Buea. (Unpublished).

IUCN. (2009). Retrieved from http://www.iucn.org/about/work/programmes/pa/pa_products/wcpa_categories

Languy, M., \& Motombe, N. F. (2003). The birds of Takamanda Forest Reserve, Cameroon. In A. J. Comiskey, C. H. T. Sunderland \& L. J. Sunderland-Groves (Eds.). Takamanda: the Biodiversity of an African Rainforest, SI/MAB (Vol. 8, pp. 95-110). Washington, D. C.: Smithsonian Institution.

Le Breton, M., Chirio, L., \& Desire, F. (2003). Reptiles in Takamanda Forest Reserve, Cameroon. In A. J. Comiskey, C. H. T. Sunderland \& L. J. Sunderland-Groves (Eds.). Takamanda: the Biodiversity of an African Rainforest, SI/MAB (Vol. 8, pp. 83-94). Washington, D. C.: Smithsonian Institution.

Mboh, H., \& Warren, Y. (2007). Large Mammal Survey of the proposed Takamanda National Park. Unpublished report to the Wildlife Conservation Society and KfW. Report 2 in the July 2007 series. Wildlife Conservation Society (WCS) - Takamanda Mone Landscape Project, Limbe, Cameroon.

MINPAT. (1987). National Population and Housing Census of Cameroon Report (p. 674).

Nchanji, A. C., \& Plumetre, A. J. (2003). Seed germination and early seedling establishment of some elephant dispersed species in Banyang-Mbo Wildlife Sanctuary, Southwestern Cameroon. Journal of Tropical Ecology, 19, 229-237. http://dx.doi.org/10.1017/S0266467403003262

O’kah, M. E. (2003). Butterfly Fauna of Takamanda Forest Reserve, Cameroon. In A. J. Comiskey, C. H. T. Sunderland \& L. J. Sunderland-Groves (Eds.). Takamanda: the Biodiversity of an African Rainforest, SI/MAB (Vol. 8, pp. 55-72). Washington, D. C.: Smithsonian Institution.

Sebogo, L. (2006). Action Plan for the management of elephants in the Ziama-Wenegesi Transfrontier corridor. Guinea-Liberia. Report from workshop held from $29^{\text {th }}$ to $31^{\text {st }}$ May 2006 in N'zerekore (Guinea) (p. 31). 
Sunderland, T. C., \& Tchouto, P. (1999). A Participatory Survey and Inventory of Timber and Non-Timber Forest Products of the Mokoko River Forest Reserve, SW Cameroon. Unpublished report for USIAD/CARPE.

Sunderland-Groves, J., Sunderland, T., Comiskey, J., Ayeni, J., \& Mdaihli, M. (2003). Takamanda Forest Reserve, Cameroon, In A. J. Comiskey, C. H. T. Sunderland \& L. J. Sunderland-Groves (Eds.), Takamanda: The Biodiversity of an African Rainforest, SI/MAB (Vol. 8, pp. 1-8). Washington, D. C.: Smithsonian Institution.

Sunderland-Groves, L. J., \& Maisels, F. (2003). Large Mammals of Takamanda Forest reserve, Cameroon. In A. J. Comiskey, C. H. T. Sunderland \& L. J. Sunderland-Groves (Eds.), Takamanda: the Biodiversity of an African Rainforest, SI/MAB (Vol. 8, pp. 111-128). Washington, D. C.: Smithsonian Institution.

Tchamba, M. N., \& Seme, P. M. (1993). Diet and feeding behaviour of the forest elephant in Santchou Reserve, Cameroon. African Journal Ecology, 31, 165-171. http://dx.doi.org/10.1111/j.1365-2028.1993.tb00529.x

Vick, S. G. (2003). Biodiversity assessment of the Ordonate fauna of Takamanda Forest Reserve, Cameroon. In A. J. Comiskey, C. H. T. Sunderland \& L. J. Sunderland-Groves (Eds.), Takamanda: the Biodiversity of an African Rainforest, SI/MAB (Vol. 8, pp. 73-82). Washington, D. C.: Smithsonian Institution.

White, F. (1993). The vegetation of Africa. UNESCO Publications (Vol. 126 No. 52), Paris.

White, L. J. T. (1994). Biomass of rainforest mammals in the Lope reserve Gabon. J. Animal Ecology, 63, 499512. http://dx.doi.org/10.2307/5217

Whitehouse, A. (2002). Conserving Addo's Elephants. The Past Present and Future of the Populations. Retrieved from $\mathrm{http} / \mathrm{www}$.scienceinAfrica.co.za/2002/march/addo.htm

WWF Cameroon Coastal Forest Programme. (2003). Large mammals survey in the Mount Nlonako, Makombe and Ebo proposed protected areas. Yaounde: WWF Cameroon, WWF, Gland, Switzerland.

\section{Copyrights}

Copyright for this article is retained by the author(s), with first publication rights granted to the journal.

This is an open-access article distributed under the terms and conditions of the Creative Commons Attribution license (http://creativecommons.org/licenses/by/3.0/). 